\title{
The Geography of Hunger: 75 years
}

In September, Brazil and the world celebrated an event that despite the millennial resilience of its study problem, is changing the course of its own civilization: the $75^{\text {th }}$ anniversary of a prophetic and even revolutionary book, Josué de Castro's, The Geography of Hunger. ${ }^{1}$ In fact, only now, three quarters of a century later, we gain the temporal perspective to understand the anticipation of the future and, therefore, its prophetic dimension and the apostolic militancy of its author, who adopted a fight against hunger as a major cause of his own life. In this missionary commitment, alongside a strength of faith, the author invests himself with an apostolic (or at least heroically militant) charge: the universal right to access basic food as a fundamental attribute of citizenship. This would be the ethical principle of food and nutritional security that Brazil has adopted in its own constitution, which is in our Carta Magna2 (Magna Letter).

The Geography of Hunger was generated, emerged, consolidated, and, above all, multiplied as a book in continuous replication of human and universal messages, more than the object of a medical-social theme, overcoming the chains of conduct in political doctrines at the time, in geographic space of ideological and political schemes and founded as a counter-culture: the transnational and pangeographic human right, with the most elementary right to healthy food. It all begins (but does not end) when, as a physician in an industry, Josué de Castro observed that the matrix disease of almost all the illness of the body was hunger. A food survey of 700 families in a neighborhood in Recife extended to domestic costs with housing, clothing, schooling, transportation and health, thus constituted an integral sketch of what would be the current family budgets, starting from the elementary observation that in a standard family at the time (1932) father, mother and five children constituted a unit of irrefutable and universal demands. ${ }^{3}$ And, in a perspective then, still futuristic, leisure itself is, or would be a basic need. Thus, we approach a cost very close to what would be a basic salary for family expenses and their essential demands with the acquisition of 12 food items referring to the demands on calories, proteins, vitamins, minerals, (macro and micronutrients) and their functions isolated and combined in a harmonic and physiologically appropriate manner. ${ }^{4}$ It was an enormous advance, at a time when even the rich and politically and culturally developed countries were involved in issues that were still so primitive, such as hunger, food insecurity, and a whole structure of adversities, which can be enunciated in the so-called "ecosystem" of poverty. It is a process sustained by the instability of employment and income, by precarious housing and sanitation conditions, by the limited supply and low quality of health actions, by the culture of poverty and even indigence that scatters around the world niches of families united or stigmatized by the apparent fatalism of poverty.

It is clear that these situations in which sociology of poverty has called "poverty villas" in Latin America, are multiplied by urban or rural agglomerations in the Third World countries, especially in Equatorial Africa, without being understood as a geographical fatalism or racial condemnation. Certainly, domestic inheritance, generation after generation, has shaped the false stigma of an atavistic inheritance of poverty and indigence. The Geography of Hunger is readily opposed to the result of a "population law": the arithmetic growth (2, 4, 6, $8,10 \ldots)$ of food supply against the population geometric growth $(2,4,8,16,32 \ldots)$. The mismatch of these two equations would be the very root of the problem in a Malthusian view. And, in this perspective, epidemics, "natural diseases" and wars would function as disposals of population excesses to restore the balance of the equation of Malthus, the historical demography founder.

The Geography of Hunger highlighted that food shortages and their millions of victims are not a purely natural event, but a result of human processes. That is, the way food on our planet is produced and commercially 
distributed, under the biased law of offering and demand, governed without any symmetry of rights and norms among users, in other words, the entire human population. The book was published in 20 languages, including Sanskrit, an extinct language, as is Latin, but what we want to highlight is Josué de Castro's contribution to reposition in other matrixes of analysis in the matter of hunger in Brazil. This change in treatment, which was reaffirmed and consolidated in the Geopolitics of Hunger, in addition to the unprecedented editorial success, made possible in Brazil, the establishment of the minimum wage, the basic laws of the Previdencia Social (alike Social Security), the institution of Merenda Escolar (Meals at School), until this day, it is one of the largest food support programs in the world, the iodation of salt for human consumption to prevent endemic goiter, the network of Previdencia Social restaurants and, above all, the creation of state and city councils for food and nutritional security. ${ }^{4}$ And, perhaps the greatest achievement, a collegial effort of public authorities and civil representatives of society made it possible to remove our country from the "hunger map", creating a historical example used by the United Nations as a benchmark platform for countries of the community or poor countries as Africa, Asia, and Latin America. ${ }^{5}$

With a commendable sense of opportunism and historical responsibility, when several events and processes were developed in Brazil and on a global scale such as the case of the tragic COVID-19 pandemic, expanding rapidly in to all the continents and to almost every country on the globe, Brazil, with a determined support of institutional organizations, such as: OXFAM Brazil, FREDERICH/EBERT/STIFTUNG Brazil, and more active National agencies of its own country to document very unique changes in the public life and in the Brazilian society itself over more recent times. We are referring to the document "food insecurity and COVID-19 in Brazil" which compounds the serious conjunction of political factors, economic crisis, dismantling of government programs, and cracks in the beams painfully built through 25 years of democratic experience. 6

And what did the State reveal about food insecurity and COVID in Brazil? In the language of Candor, as Josué de Castro's way of communicating in his classical books, food insecurity is returning to the scenarios of the population in the country. Thus, among 212 million inhabitants, almost 117 million live in some level of food insecurity, which represents more than $55 \%$ of the entire population. And remember that a little more than a decade ago, Brazil offered lessons to the world by leaving the complicated "hunger map" to consistently advance in the vanguard of food and nutritional security.

Now, with $14 \%$ of the labor force deactivated by unemployment, with more than $55 \%$ going hungry, with poverty in rural areas exceeding more than twice the negative levels of urban poverty, food insecurity restores areas of the geography of hunger and draws a dark and discouraging picture for the new legions of inhabitants who suffer the threat and harshness of the reality documented by Josué de Castro 75 years ago. 6

\section{References}

1. Castro J. Geografia da fome (o dilema brasileiro: pão ou aço). 10 Ed. Rio de Janeiro: Antares Achia-mé; 1980.

2. Brasil. Lei $n^{\circ} 11.346$, de 15 de setembro de 2006. Cria o Sistema Nacional de Segurança Alimentar e Nutricional - SISAN com vistas em assegurar o direito humano à alimentação adequada e dá outras providências. Diário Oficial da União [DOU]. Brasília, DF, 18 set 2006; Seção 1.

3. Castro J. Condições de vida das classes operárias do Recife. Departamento de Saúde Pública, Recife; 1935.

4. Andrade MC. Josué de Castro: o homem, o cientista e seu tempo. Estud Av. 1997; 11 (29): 169-94.

5. FAO (Food and Agriculture Organization of the United Nations), IFAD (International Fund for Agricultural Develoment), WFP (World Food Programme). The state of food insecurity in the world 2014: Strengthening the enabling environment for food security and nutrition. Rome; 2014. [acesso 10 set 2021]. Disponível em: http://www.fao.org/3/i4030e/i4030e.pdf

6. VIGISAN (Vigilância Segurança Alimentar e Nutricional). Inquérito Nacional sobre Insegurança Alimentar no contexto da pandemia da COVID-19 no Brasil, 2021. [acesso 10 set 2021]. Disponível em: https://pesquisassan.net.br/olheparaafome/

Malaquias Batista Filho 1

iD https://orcid.org/0000-0002-1490-0590

Déborah Lemos Freitas 2

(iD https://orcid.org/0000-0002-6068-8623

1,2 Instituto de Medicina Integral Prof. Fernando Figueira. Rua dos Coelhos, 300. Boa Vista. Recife, PE, Brazil. CEP: 50.070-902. 